\title{
SCIENTIA HISTORICA E PHILOSOPHIA POLITICA NO TRATADO SOBRE A TRANSLAÇÃO DO IMPÉRIO DE MARSÍLIO DE PÁDUA
}

\author{
José Antônio de C. R. de Souza*
}

SÍNTESE - Marsilio de Pádua, embora não tenha escrito sobre Teoria da História, contudo oferece pistas para analisar-se como a ciência histórica estava formulada no século XIV. Pela leitura de seus textos, vê-se como formulou a teoria a partir de fatos candentes de seu tempo.

PALAVRAS-CHAVE - Marsilio de Pádua, Filosofia politica medieval, Teoria da História.
ABSTRACT - Though he didn't write anything about the theory of history, Marsilius of Padua however points out clues in order to analyse how the historical science was formulated in the fourteenth century. Through the texts it becomes clear how he has formulated the theory starting from real facts of his time.

KEY WORDS - Marsilius of Padua, medieval political philosophy, theory of history.

Quase ao final de O Defensor da Paz, Marsilio de Pádua escreve o seguinte: "Quanto ao que está escrito no capítulo VII de certos textos designados por decretais, intitulado Sobre o juramento, e numa carta de alguém que se diz Papa, dirigida ao ínclito Luís, duque da Baviera, eleito Rei dos Romanos, que o Império Romano foi transferido dos Gregos para os Germânicos na pessoa de Carlos Magno, pela Sé Apostólica [...] de conformidade com a Justiça, deixemos essa hipótese de lado por agora, pois num outro tratado iremos discutir a respeito dessa transferência, e como de fato ela aconteceu". ${ }^{1}$

O Paduano revelava, pois, sua intenção de tratar particularmente deste assunto de natureza eminentemente histórica, e é o que de fato fez no opúsculo que escreveu algum tempo depois de sua obra principal, intitulando-o Sobre a Translação do Império, ${ }^{2}$ cuja tradução apresentamos ao final deste trabalho, sob o Apêndice I.

* Universidade Federal de Goiás.

1 Defensor da Paz, ed. em português José Antônio de SOUZA, Petrópiis, Vozes, 1997, II Parte, capitulo XXX, § 7: 684.

2 Utilizamos a edição crítica bilingüe do mesmo intitulada Marsile de Padoue Oeuvres Mineurs Defensor Minor De Translatione Imperii, publicada por C.JEUDY e J. QUILLET, Paris, CNRS, 1979. A introdução ao texto se encontra às páginas 315-367, e o tratado com o aparato crítico, às páginas 371-433.

\begin{tabular}{|l|l|l|l|l|l|}
\hline VERITAS & Porto Alegre & v. 43 & $\mathrm{n}^{0} 3$ & Setembro 1998 & p. 643-655 \\
\hline
\end{tabular}


Portanto, a obra visa a "traiter de l'E'mpire romain, de son fondement et de sa légitimité à l'épreuve de l'Histoire, en tant qu'il constitue 'la monarchie universelle ou génerale du monde entier [...] d'administrer la preuve du bien-fondé historique de la légitimité de l'Empire romain, de son universalité, de son autonomie et de son indépendance". ${ }^{3}$

Tínhamos igualmente o desejo de fazer isso, como o dissemos à Introdução ${ }^{4}$ ao O Defensor da Paz, e a ocasião para tanto surgiu a partir da temática geral deste VI Simpósio de Filosofia Medieval, organizado pela presidência da Comissão de Filosofia Medieval do Brasil, a qual versa, como é do conhecimento de todos, sobre a Estrutura do saber e teoria da ciência. Com efeito, pensamos, de um lado, em verificar no texto de Marsílio, como o saber ou a ciência histórica estava concebida e formulada no século XIV, e de outro, como ele, na condição de médico e pensador político, portanto, não cronista ou historiador, no sentido mais amplo da palavra, serviu-se de fatos históricos para formular uma teoria sobre um assunto candente em sua época, e refutar a tese oposta, apresentada por Landolfo Colona, ${ }^{5}$ em seu opúsculo Tractatus de translatione imperii a Grecis ad Latinos, ${ }^{6}$ possivelmente escrito entre 1317-24, cujo objetivo principal consistiu "montrer que la translatio imperii a été effectuée par l'autorité pontificale et que par conséquent le pouvoir impérial est sous la dépendance de cette autorité", 7 obra essa que faz parte do vasto material produzido pelos hierocratas durante a última querela medieval entre o Papado e o Império (1314-50). Por sinal, logo nas primeiras linhas do tratado, o próprio Paduano declara que tem a intenção de rebater pequeno tratado de Londolfo "quoniam eius scripturae in quibusdam nostra sententia dissonat, praesertim in quibus iura lesit Imperii secundum sententiam propriam absque probatione sufficienti $[. .$.$] ". Ao empreendermos esta pesquisa, ainda tivemos a$ intenção de verificar também quais os aspectos filosófico-políticos marcantes existentes nesta obra.

Antes, porém, de tratarmos dos objetivos que acabamos de indicar, convém primeiramente dizer algo sobre a disposição interna do tratado. Ele principia com um sumário do que. irá ser exposto, mais adiante, e termina com um capitulo, o décimo segundo, que é um resumo do que foi narrado nos onze capítulos precedentes, os quais se dividem em duas partes, uma com seis, a outra com cinco capítulos, "bien distinctes: la première, consacrée à l'histoire de Rome et de l'empire romain, la seconde consacrée à la translatio proprement dite, ces deux parties étant encadrées par les attendus théoriques visant à poser la notion même de translatio au niveau de la raison et du droit [...]".

3 Cfr. Introdução, p. 365.

4 Introdução, p. 13.

5 Esse clérigo pertencia à célebre familia romana dos Colonna. Cônego em Chartres, especialista em Direito Canônico, escreveu várias obras histórico-políticas. Depois de ter passado algum tempo na corte papal de Avinhäo, regressou a Roma, onde faleceu, à volta de 1331.

6 Partes relevantes desta obra constam do Apêndice II, deste trabalho. Servimo-nos da edição de M. GOLDAST, Francofordiae, 1614, vol. II: 88-95.

7 J. Quillet, C. Jeudy, Introdução, p. 315.

8 Ed. cit. p. 374. 
Isto posto, antes de tudo, não nos parece despropositado recordar que desde a segunda metade do século XIII, no Ocidente latino os cronistas, ou historiadores de então, passaram a desempenhar um relevante papel cultural, na condição de preservadores da memória das gestas de um povo ou de uma instituição ou de um grupo social, mister esse que se tornou mais importante, ainda a partir da Idade Média Tardia, quando da emergência e consolidaçằo das monarquias nacionais. Para não irmos buscar exemplos longínquos das nossas raízes peninsulares, baste mencionar os cronistas lusitanos Fernão Lopes (séculos XIV-XV), Rui de Pina (século XV) e o castelhano Pero López de Ayala (1332-1407), igualmente chanceler de Castela.

Tal fato, porém, não quer dizer que os medievais anteriormente não tivessem cultivado o gênero literário genericamente designado por nós historiográfico. Sem fazer menção específica aos antigos martiriológios, aos Annales, às higiografias, às Legendae, às Tabulae Chronologicae, ao Liber Pontificalis, lembremo-nos, de passagem, de Gregório de Tours ${ }^{9}$ (século VI), Isidoro de Sevilha ${ }^{10}$ (séculos VI-VII), Beda o Veneráve ${ }^{11}$ (séculos VII-VIII), Paulo Diácono, ${ }^{12}$ e Eginhardo. ${ }^{13}$ Igualmente as ordens monásticas, as abadias e mais tarde as ordens religiosas, as províncias em que elas foram divididas e organizadas também possuíram os seus cronistas, conhecidos ou anônimos.

Um dos paradigmas da produção historiográfica medieval foi a Bíblia, vista igualmente como um texto contendo um bom número de livros históricos, cuja fundamentação teórica baseou-se no providencialismo divino, a par da luta constante entre o bem e o mal, e na escatologia. Com efeito, Deus, ao se revelar nas Escrituras, não estaria mentindo aos homens. Por isso, de um lado, o ponto central de toda produção historiográfica daquele tempo gravita em torno da Encarnação, Paixão e Ressurreição de Cristo, o centro da História, e de outro, em mostrar no decorrer dos tempos históricos o desenrolar de um plano divino de salvação, cuja efetivação aparenta ser constantemente prejudicada pela ação do mal, o qual, entretanto, ao final dos tempos, será definitivamente vencido, uma vez que a Salvação já aconteceu.

As obras mais relevantes, que estabeleceram este modelo teórico pela influência que exerceram nos pósteros, foram a História Eclesiástica de Eusébio de Cesaréia, (séculos III-IV), através de sua versão latina escrita por S. Jerônimo, (séculos IV-V) e intitulada Chronica Ecclesiastica, ${ }^{14}$ e a Historia adversos Paganos

9 Legou-nos a Historia ecclesiastica francorum, in PL 71.

10 O Bispo hispalense escreveu, entre outros livros de caráter histórico, o Chronicon majus, in PL, 83: 1017-1058, e o De viris Ilustris, ibidem.

11 Autor da célebre Historia Ecclesiastica gentis Anglorum.

12 Esse clérigo italiano que viveu no século VIII, nos deixou algumas importantes obras históricas: Historia romana, De gestis epis. Metensis, De gestis longobardorum e Notitia de unctione Pippini, in MGH Ss, vol. I.

12 Esse clérigo italiano que viveu no século VIII, nos deixou algumas importantes obras históricas: Historia romana, De gestis epis. Metensis, De gestis longobardorum e Notitia de unctione Pippini, in $M G H$ Ss, vol. I. Monge, conselheiro, agente do renascimento carolíngio e biógrafo de Carlos Magno, Eginhardo (séculos VIII-IX) escreveu a famosa Vita Caroli.

14 Encontra-se publicada na PL, 27. 
de Paulo Orósio ${ }^{15}$ (séculos IV-V). Para além daqueles dois aspectos, há pouco mencionados, há ainda um terceiro, a visão filosófica da história dos homens e do mundo, haurida na filosófica neoplatônica, cristianizada particularmente através da pena de Santo Agostinho (séculos IV-V) em A Cidade de Deus. ${ }^{16}$

$O$ outro modelo paradigmático teórico para os medievais foi aquele deixado principalmente pela historiografia romana (e greco-helenística), primeiramente transmitido pelos antigos escritores cristãos, depois pelos mencionados autores imediatamente acima referidos e, mais tarde, pelos monges copistas.

Ora, para aqueles autores e para os medievais, em geral, o tema da transferência do poder supremo ou universal de uma nação para outra e a respectiva hegemonia exercida sobre as demais, a começar dos babilônios e persas, passando pelos macedônios até chegar aos romanos, esteve sempre presente em suas mentes, seja em razão tanto dos relatos bíblicos, quanto dos profanos.

Herdeiros do Bispo de Hipona, embora o contexto histórico e os propósitos respectivos de seus autores tivessem sido outros, foram Otão, bispo de Freising (século XII) e a sua Chronica ou De Duobus Civitatibus, ${ }^{17}$ João de Salisbúria, autor do Policraticus ${ }^{18}$ e de uma Historia Pontificalis.

A par dessas considerações preliminares, um outro dado relevante, encontrado nas obras de filósofos políticos que viveram na Idade Média Tardia, consistiu em recorrer aos relatos históricos (recentes e ou remotos) como mais uma via ou caminho para demonstrar que os adversários estavam errados quanto à teoria, à posição e à verdade que pretendiam defender. Dante Alighieri na Monarquia ${ }^{19}$ Marsílio no Defensor da Paz ${ }^{20}$ e Ockham em muitos de seus tratados, por exemplo, na Epistula, ${ }^{21}$ no An Princeps, ${ }^{22}$ no Brevilóquio, ${ }^{23}$ na Consulta ${ }^{24}$ e no De Imperatorum et Pontificum Potestate ${ }^{25}$ usaram este recurso. Aliás, o primeiro filósofo

15 Viveu na Peninsula Ibérica durante os séculos IV-V. Escreveu o Liber Apologeticus e as Historiae, que é vulgarmente conhecida sob o título referido. Encontra-se publicada na $P L, 31$.

16 Dispomos de uma edição dessa obra em português, publicada pela Editora Vozes.

17 Vide R.A. da Costa Nunes, "Reflexões sobre a Crônica ou A História das duas Cidades, in Pensamento Medieval (Org.) José Antônio de Souza, Santos-S. Pauio, Leopoldianum/Ed. Loyola, 1983: 70-86. Otão também escreveu uma outra obra de caráter histórico intitulada Gesta Friederici I Imperatoris, dedicada ao seu sobrinho Barba Ruiva.

18 Cfr. a propósito, a dissertação de mestrado em Filosofia Politica de minha orientanda, Eliana Borges Fleury Curado, intitulada A Concepção de Monarquia em John de Salisbury, 215 p., policopiada, apresentada e defendida junto ao Departamento. de Filosofia da Universidade Federal de Goiás, 1997.

19 Cfr. a tradução em português de C. do SOVERAL, col. Os Pensadores, vol. 8, S. Paulo, Ed. Abril, $1^{\text {a }}$ ed., Livro-IIF-p.205-218; Livro III, in fine, onde o autor defence a tese que o império procede exclusivamente de Deus, não da Igreja, por intermédio do papa.

20 Cfr. nossa tradução dessa obra, Petrópolis, Vozes, 1997. Reportamo-nos particularmente aos capitulos XXV e XXVI da $2^{2}$ Parte, p. 553-600.

21 Ed. H.S. OFFLER, Guillelmi de Ockham Opera Politica, vol. II, Manchester, MUP, 1956, p. 6-17, em particular, p. 6-7, 8, 10-11, 15-17.

22 Ed. H.S. OFFLER, Guillelmi de Ockham Opera Politica, vol. I, $2^{\text {a }}$ ed., 1974, capitulo II, p. 231, 235, capitulos VII e VII, p. 252-257.

23 Cfr. a tradução em português de L.A. DE BONI, Petrópolis, Vozes, 1988, Livros III e IV, p. 95-154.

24 Cfr. nossa tradução desse opúsculo in Pensamento Medieval Santos-S. Paulo, Leopoldianum/Ed. Loyola, 1983: 177.

25 Ed. H.S. OFFLER, William Ockham Opera Politica IV, Oxford, OUP, 1997: 279-355, em especial os capítulos XVII-XXVI: 311-325. 
político medieval, João de Salisbúria, no Policraticus, agiu dessa maneira, como outrora já haviam feito Platão e Aristóteles em seus escritos políticos, estabelecendo, até certo ponto, um dentre outros paradigmas metodológicos em que se baseia a Filosofia Política, qual seja, os dados que a História lhe fornece, posto que são scientiae empinicae, infelizmente prescindiveis, ainda hoje, por muitos investigadores da Filosofia Medieval, no Brasil e no estrangeiro, sob a alegação, entre outras, de que àquela época a reflexão política não gozava de autonomia científica. Todavia, este assunto, conquanto seja importante sob os aspectos teóricometodológicos, merece uma discussão mais ampla, que fugiria do cerne deste trabalho.

Em vista, pois, daqueles paradigmas antes mencionados e pressupondo, com os autores que acabamos de referir, em particular, com o próprio Marsílio, que os adversários, nomeadamente os hierocratas, escreviam inverdades, cabe, então, indagar qual foi o critério de escolha documental que ele utilizou para escrever o opúsculo Sobre a Translação do Império?

A leitura do mesmo nos revela imediatamente que ele, de propósito, omitiu aludir ou citar, ainda que fosse para discutir e redarguir, todos os textos históricolegais contidos no Decreto, nos Livros das Decretais e nos Aparatos, e as razões para tal procedimento, adotadas pelo Paduano, reduzem-se a três, anteriormente explicitadas em $O$ Defensor da Paz. Quanto à primeira razão, ele diz o seguinte: "No tocante à confirmação das objeções que foram tiradas dos Decretos ou Decretais dos Pontífices Romanos, respondemos afirmando que, em geral, é preciso rebater todos esses textos e argumentos, os quais não são do mesmo teor daqueles a que nos referimos no capítulo XIX desta Parte [§ § 1-7], porque não somos obrigados a acreditar que sejam verdadeiros, nem concordamos com eles naquilo que se opõem aos nossos pontos de vista em perfeita consonância com os ensinamentos da Escritura, e por isso, com o devido respeito, os negamos e deles nos afastamos". ${ }^{26}$ A segunda e a terceira razões estribam-se em alguns pontos fulcrais de sua concepção filosófico-política, elaborada sistemática e amplamente naquela obra, segundo os quais, os clérigos, em geral, incluído o sumo pontífice, dado que entre eles não há nenhuma diferença no que respeita ao poder sacramental que exercem em proveito dos fiéis, não receberam de Cristo uma jurisdição, um poder político para ser exercido sobre ninguém, muito menos sobre a esfera temporal; ${ }^{27} \mathrm{a}$ autoridade política suprema, exercida sobre uma sociedade, é una e indivisa, conquanto, por delegação de competência, possa vir a ser confiada a terceiros ${ }^{28}$ Por sinal, Marsílio. deixa bem claro no princípio, na metade e no final do opúsculo em exame ${ }^{29}$ que, ao escrevê-lo, se apoiou nas teses que já havia tratado e comprovado em sua obra principal, a qual, por este motivo, consideramos que também deva ser tida na conta de fonte para o mesmo, no que respeita à sua base filosófico-política.

Op. cit., Parte II, cap. XXVIII, § 28: 657.

Cfr. Defensor da Paz, II, capitulos II-VII, p. 215-294, capitulos XV-XIX, p. 407-477.

Cfr. Defensor da Paz, I Parte, capitulos XII-XVII, páginas 129-189.

29 Cfr. respectivamente ed. cit., capítulo I, p. 374, capítulo VI, p. 402, e capítulo XII, p. 432. 
No entender de Marsílio, portanto, as fontes escritas por clérigos, atribuindo a certas pessoas de seu grupo, isto é, aos membros da hierarquia eclesiástica, um poder, uma autoridade política, pouco importa a sua extensão, sobre eles próprios, e principalmente sobre o âmbito secular, não podem lhes servir de suporte para a Hierocracia, e seu corolário, a plenitudo potestatis, porque elas, e particularmente os textos legais, carecem de fundamento, seja, para além do que escrevemos, pelo fato de no Novo Testamento e nos comentários fidedignos ao mesmo, escritos pelos Padres da Igreja, não haver uma passagem que as respalde, seja ainda, porque, especificamente, no tocante à translação do poder imperial, externam uma ambição sub-reptícia desse grupo, de modo que, por exemplo, acerca da deposição de Childerico e da entronização de Pepino o Breve, em seu lugar, é preciso "clericorum vero scriptura in hoc reicienda, posto que ainda são Francis praeiudicalis et falsa, ${ }^{30}$ pois eles, sibi alienam auctoritatem usurpare quaerentium", ${ }^{31}$ visam mediante esses textos se atribuir algo que não possuem. Aliás, neste trecho do opúsculo, percebe-se a crítica implícita de Marsílio ao passo do Decreto, distinção $\mathrm{XV}$, onde se encontra o capítulo Alius, em que se afirma que foi o papa Zacarias que ordenou a deposição de Childerico, bem como a entronização de Pepino o Breve, fatos esses que Landolfo Colonna aduz em seu tratado, dizendo que foram verídicos e perfeitamente legítimos e legais. ${ }^{32}$

Embora o Paduano sustente que se apoiou em Aimo de Fleury para dissentir de Landolfo, não descartamos a hipótese de que ele tenha compulsado a Quaestio in utramque partem, apesar de o seu teor, em geral, ser favorável às pretensões de autonomia e hegemonia políticas aspiradas por Felipe o Belo (1285-1314), pois o trecho alusivo ao assunto predito assemelha-se muito com a do tratado em questão: "Respondo ao argumento, afirmando que não se lê em texto algum que o rei dos Francos foi deposto pelo Papa Zacarias. Na verdade, segundo afirmam algumas pessoas, aquele Papa foi consultado acerca da deposição. Com efeito, indagado sobre quem deveria efetivamente reinar, se a pessoa que zelava pelos negócios do reino ou aquele que não o fazia, Zacarias respondeu que deveria ser o primeiro. Assim, o rei Childerico foi deposto pelos barões e Pepino foi ordenado e ungido rei. Outras pessoas dizem que o rei Childerico não foi deposto, mas ingressou espontaneamente num mosteiro, abraçando a vida religiosa. Daí, como os barões do reino hesitassem sobre se lhes seria lícito escolher e instituir Pepino como rei, consultaram o Pontifice Romano a tal respeito. Mas poderiam ter feito isso, sem a necessidade de o consultarem [...]". ${ }^{33}$

Todavia, parece que Marsílio não dispôs de outra alternativa senão aquela de ter de recorrer aos textos histónicos escritos por clérigos, tendo utilizado as obras, entre outras, conforme o peso de sua influência, da autoria de Martinho Polonês O.P. (século XIII), aliás, a quem ele havia duramente criticado no Defensor da

30 Ed. cit., cap. VI, p. 402.

31

Ed. G. VINAY, in BISIME, 53 (1939): 93-136. O trecho traduzido se encontra à p. 134. 
$\mathrm{Paz}^{34}$ de Aimo de Fleury, de Ricardo de Cluny e de Sicardo de Cremona ${ }^{35}$ (séculos XII-XIII), que as editoras do opúsculo indicam e, muitas vezes, transcrevem passagens sob a forma de notas de rodapé, enriquecidas, ainda, com um preciso aparato bibliográfico.

Ainda, com referência às fontes que Marsílio utilizou na obra em tela, acreditamos e julgamos importante ressaltar que ele também se baseou, em muitas passagens, quase ipsis litteris, em um outro opúsculo intitulado Tractatus de Origine ac Translatione et status Romani Imperii, atribuido a Ptolomeu de Lucca O.P (1236-1326/7), famoso discipulo de Tomás de Aquino (1226-74), exímio historiador e canonista, tratado esse escrito à volta de 1300,36 cujas partes semelhantes constituirão o Apêndice número II, apresentado ao final da tradução n. 2, nesta revista. Entretanto, embora saibamos que entre os medievais era comum a apropriação de textos escritos por outrem, seja para assumir como suas as idéias propostas por um outro autor, cuja obra podia servir de fundamentação para a própria, seja para o refutar, no presente caso, para além de Marsílio afirmar, logo no princípio de seu tratado, que pretende criticar o texto de Landolfo "quoniam eius scripturae in quibusdam nostra sententia dissonat, praesertim in quibus iura lesit Imperii secundum sententiam propriam absque probatione sufficient", ${ }^{37}$ fato este que nos obriga a admitir que tenha procedido daquela maneira, face à segunda alternativa que acabamos de referir, consideramos que ele absolutamente não foi nem um pouco original ao escrevê-la, atendo-se quase ad litteram ao texto de Landolfo. Por sinal, é o que observam as editoras do texto de Marsilio, o qual "est généralement consideré comme un pur et simple décalque de l'ouvrage du même nom de Landolfo Colonna [...]". 38

Ademais, um outro motivo que nos leva a acreditar que o Paduano compulsou o opúsculo de Ptolomeu de Lucca, face à similitude do mesmo com o tratado de Landolfo Colonna, e o objetivo hierocrático que ambos tinham em mente, qual seja, o de sustentar que as translações imperiais e o estabelecimento do colégio de príncipes eleitores foram efetuados pelo papado, é ter-lhe apresentado a oportunidade de tentar refutar as duas obras ao mesmo tempo. Outrossim, não nos parece descabido pensar que Landolfo igualmente o tivesse tido em mãos, e dele se apropriou, por julgar que se prestava muito bem aos seus aludidos propósitos..

34 Cfr., op. cit., Parte II, capítulo XXV, § 8: 561-562: “Ora, conquanto tenha escrito, a respeito de Leão $X$ [?], que segundo um costume pernicioso, os romanos solicitaram ao Imperador que lhes desse um pontifice [ibidem: 433], se bem que ele admitisse que isso era um costume, idéia com a qual concordamos, em razão de ser verdadeira, todavia ao ter afirmado por auto-iniciativa que o mesmo era pernicioso, absolutamente näo estava a dizer a verdade, porque na medida em que podia justificava as usurpações dos Pontífices Romanos, mascarava os direitos dos príncipes e do legislador humano, e se esforçava antes por agradar mais aos homens do que a Deus e ainda em não ser honesto...Contudo, não podemos nos fiar no testemunho de Martinho sobre esse fato, porque ele e sua Ordem tomaram parte numa usurpação semelhante à que estamos analisando...".

5 MGH Ss., ed. L. WEL_AND, tomo XXII: 377-345; Historia Francorum a Troja capta ad anno 654, in PL, 139, 627-798; Chronicon, ed. MARTĖNE, Amplissima Collectio, vol. V: 1159-1174; Sicardi Chronicon, in PL, vol. 213.

Ed. M. KRAMMER, Fontes Iunis Germanici Antiqui, MGH, Hannoverae, 1909: 66-75.

Ed. cit., p. 374.

Introdução, p. 315. 
Importa, agora, dizer de que modo Marsilio utilizou as fontes que ele reputa fidedignas. Um dado que chama a atenção do leitor que conhece as suas obras é o fato de ele não transcrever passagens dos textos em que se apóia, agindo diferentemente do que havia feito, por exemplo, no Defensor da Paz, e mais tarde o irá fazer no Defensor Menor. Ora, com certeza ele sabia que esse procedimento, já bastante comum em sua época, diminuía o peso de seu tratado, ainda que seus oponentes também tivessem agido do mesmo modo.

A par disso, falta igualmente neste tratado uma critica textual da parte de Marsílio, ao menos no que concerne aos fatos históricos importantes para os temas que ele tinha elegido descaracterizar nas obras de seus adversários. Ele simplesmente os aceitou como verídicos, oferecendo, na verdade, a impressão de que se fiou em que os mesmos tivessem recorrido, de fato, a fontes fidedignas. Com efeito, se ele tinha anteriormente posto em dúvida, como vimos atrás, a honestidade dos relatos apresentados por Martinho Polonês, é de estranhar que tenha recolhido suas informações sem, pelo menos, ter reiterado a crítica que antes lhe fizera, pelo menos à guisa de advertência para seus leitores. Sob a abordagem em tela, julgamos que os dois trechos mais vulneráveis do opúsculo são os seguintes: o primeiro encontra-se pela metade e no final do capítulo segundo. Refere-se à instituição do cardinalato e, por duas vezes, Marsílio afirma que tal dignidade foi estabelecida por são Silvestre, a pedido dos presbiteros da Urbe. Todavia, após discorrer sobre o número dos cardeais e a subdivisão hierárquica existente entre eles, (6 bispos, 28 presbíteros e 18 diáconos) baseando-se, segundo ele, em Martinho Polonês, assevera haver outros mais, conforme os títulos pelos quais são designados, enfatizando que estes foram anteriormente dados pelos papas Cleto, Anacleto e Marcelino, os quais viveram respectivamente nos séculos II e III.

A segunda passagem é aquela que se encontra bem no início do capitulo onze e cujo arremate conclusivo encontramos na última frase do citado capítulo. Marsílio, Landolfo e Ptolomeu, primeiro, afirmam que o colégio eleitoral, incumbido de eleger o Imperador, foi estabelecido durante o pontificado de Gregório V, declarando que se fundamentaram em Martinho Polonês, o qual, na verdade, absolutamente não diz tal coisa, como poderá ser verificado no Apêndice I, na nota alusiva à passagem em questão. Depois, entrando em contradição, asseveram, respaldados desta feita nos relatos das gestas germânicas, que o sobredito estabelecimento foi tomado em 1004, não atentando para o fato de que aquele papa já tinha falecido algum tempo antes. ${ }^{39}$ Bem a propósito, eis as palavras de Marsílio: "Cuius pontificis tempore, imperatores electores instituuntur, septem scilicet principes Alamaniae, quatuor laici et tres clerici, sive prelati, ut Martinus scribit [...] haec autem ordinatio facta fuit anno millesino quatro, ut gesta Germanorum manifeste declarant." 40

Uma outra informação histórica inverídica, endossada por Marsilio, diretamente relacionada com o tema central desta obra e que se encontra no início do

39 Cfr. Apêndice II, ed. M. KRÁMIMER, p. 72, ed. M. GOLDAST, cap. IX, p. 94-95

40 Ed. cit., p. $428,430$. 
capitulo quinto ${ }^{41}$ da mesma, concerne à assertiva segundo a qual a sé imperial teria permanecido em Constantinopla até o governo do imperador Constantino VI e de seu filho Leão, quando, então, conforme ele relata a seguir, começou a ocorrer a translação do império dos gregos para os francos. Ėle tornou a repeti-la no capítulo nono, ao se referir que o predito imperador bizantino solicitou de Carlos Magno que libertasse a Terra Santa do jugo persa, também acreditando que este fato tivesse ocorrido e que o império persa, então, dominasse a Palestina, apesar de, num longo trecho do capítulo quarto, ${ }^{42}$ ter narrado corretamente que, após a curta dominação persa sobre as provincias ocidentais bizantinas, sobreveio-lhe a expansão árabo-islâmica, liderada por Maomé e os califas seus sucessores, os quais conquistaram definitivamente o Egito, a Palestina e a Síria.

Isto posto, tendo acabado de relacionar entre si os aspetos, fontes e crítica documental, somos obrigados a discordar do ponto de vista das editoras do opúsculo, as quais afirmam que Marsílio, a par de seu objetivo principal, antes mencionado, teve em mente "confronter les récits historiques à la norme de la raison et du droit, selon la méthode de critique historique déjà exposée dans le Defensor Pacis et qui est mise à l'oeuvre [...] mais de manière systématique [...]",43 porque, como o demonstramos, eles nos parecem estar ausentes do tratado.

Falta, ainda, analisar o pequeno tratado de Marsilio sob a perspectiva da cronologia. Uma vez mais, nota-se no mesmo falhas do tipo antes referido. Com efeito, ele endossou as datas apresentadas pelos autores de suas fontes ou por seus adversários, sem ter tido a preocupação de verificar a exatidão deles, o que denota, não apenas uma certa ausência de espírito crítico, mas também uma carência de rigor criterioso. Muitos são os problemas desse tipo encontrados no texto. Bastem mencionar, por exemplo, as datas concernentes à ascensão de vários papas à Sé Apostólica; as imprecisões quanto aos periodos exatos dos governos dos imperadores Constantino Magno, Heráclio, Leão III, Otão I e dos seus sucessores imediatos, bem como à datação exata dos feitos de Pepino o Breve, Carlos Magno e Otão I. Entretanto, os dados cronológicos mais imprecisos apresentados pelo Paduano, face ao intuito principal que tinha em mente, são aqueles relativos à ocasião em que exatamente teria sido criado o sistema eletivo imperial. Com efeito, quase ao final do décimo capítulo, o Paduano diz que quarenta anos depois da aclamação de Otão I como imperador, esse procedimento foi estabelecido e, ao final do capítulo undécimo, diz que tal medida passou a vigorar em 1004. Se considerarmos a primeira referência, sabendo que Otão I foi coroado em 962, teremos a data de 1002. Levando em conta a última, isto é, 1004, ele, então, teria sido coroado em 964, ficando, portanto, evidente a inexatidão cronológica do mesmo.

Feita a precedente análise, de acordo com objetivos pretendidos, para concluir a primeira parte do trabalho, resta avaliar se Marsílio no De Translatione ofereceu ou não alguma contribuição para a historiografia, ao menos em termos gerais.

41 Cfr. respectivamente a ed. cit., p. 394-395; p. 418.

42 Op. cit.,p. 392, 394

43 Introdução, p. 344. 
Acreditamos que sim, mas para que tal ponderação seja realçada, julgamos que ela deva ser feita, conforme a própria disposição interna do tratado, organizado, como vimos, em duas partes. Nos seis capítulos iniciais, o Paduano descreveu e analisou primeiramente os fatores que contribuíram para que os romanos tivessem construído um grande e poderoso império, tendo apresentado, para tanto, razões naturais, tais como a valentia, a disciplina, a organização, o treinamento militar, as alianças militares com os povos vizinhos, o respeito às leis e à justiça etc. Depois, os motivos que levaram o antigo império à ruína, cuja sede, então, já havia sido mudada para Constantinopla. Se de um lado, em sua análise, nos deparamos com a adesão dos gregos às heresias, uma razão religiosa, verificamos igualmente a imperícia política, sob a forma de tirania, e militar dos imperadores ao governar o império, em face, por exemplo, da expansão islâmica, mais um fato religioso, levada avante pelos califas, mas deflagrada por Maomé, homem esperto, politicamente hábil, que soube conduzir nações sob o seu comando. A par desses fatores, Marsílio, em sua reflexão, também indicou outros dados, entre as quais, as rixas entre gregos e latinos, a ambição de dominar de parte do papado, como fatores para a ruina do império.

Nos seis restantes capitulos notamos que Marsílio fez uma leitura semelhante idos fatos históricos. Com efeito, no seu entender, Pepino o Breve, Carlos Magno, Otão I, seu filho e seu neto foram a tal ponto pessoas virtuosas, valentes guerreiros e hábeis governantes que, graças a tais qualidades, reconhecidas por todos, conquistaram para si muitos territórios e poder político, cujo ápice foi a coroação imperial. Ademais, católicos fervorosos, sempre devotaram enorme respeito à Igreja Romana e aos seus dirigentes, protegendo-os, guardando o seu patrimônio, sempre que foram solicitados, e ampliando-o, por causa da magnanimidade. Foi em troca destes favores recebidos, por exemplo, que alguns bispos romanos concederam primeiramente a Carlos Magno, e mais tarde a Otão I, o direito de escolher os dignitários eclesiásticos para todos os bispados e arcebispados, inclusive, para o romano e, como maior prova de reconhecimento, puseram em suas cabeças a coroa imperial. Todavia, este gesto era irrelevante, porque, antes, haviam sido aclamados imperadores pelo povo e igualmente pelo clero.

Aliás, a igreja romana e os papas romanos, expressões propositadamente muito usadas por Marsílio, de acordo com o tipo de leitura histórica que adotou para si, com o fito de destacar a sua origem puramente humana, foram pessoas ambriciosas por riqueza, honras, poder, dominação e prestígio. Levados por estes sentimentos publicaram documentos carentes de valor legal, em que afirmam que as translações e coroações imperiais, bem como o estabelecimento do colégio eleitoral do imperador, foram realizados por eles.

Na verdade, após a morte do último otônida, que não deixou descendentes, achou-se mais oportuno, considerando-se o bem comum, mudar o critério de escolha do imperador, de hereditário para eletivo, tendo este mister sido confiado a sete príncipes germânicos, três arcebispos e quatro nobres.

A contribuição historiográfica de Marsílio reside, pois, no tipo de leitura e análise que fez acerca dos fatos históricos, a qual difere radicalmente daquela 
apresentada por seus coetâneos, conforme indicamos páginas atrás, e que se caracteriza, entre outros aspectos, primeiro, por abandonar o providencialismo divino. Com efeito, não foi a Providência que quis e permitiu que o império romano, sob o controle dos gregos, tivesse desaparecido porque eles se afastaram da ortodoxia e por este motivo foram castigados por Deus. Igualmente não foi Ela que desejou e consentiu que o império continuasse inicialmente com os francos e depois com os germânicos, pelo fato de os seus líderes serem apenas católicos devotos e defensores da Igreja.

Em segundo lugar, Marsílio salienta que a história da Humanidade resulta exclusivamente da ação dos homens, bons ou maus, uns mais plenos de virtudes ou de vícios do que os outros, e que, dadas as inúmeras e variadas circunstâncias articuladas entre si, esses homens, tal qual são, podem chegar ao poder e virem a governar bem ou ser tiranos, conquanto, de acordo com a própria experiência acumulada pelos seres humanos através dos tempos, para evitar a tirania, é melhor que se eleja o governante. Enfim, para o Paduano são fatores simplesmente humanos que explicam o processo histórico e, sob esta ótica, ele dessacralizou a História, antecipando-se no tempo, a uma análise interpretativa dos fatos históricos que só veio a se tornar corrente com a Idade Contemporânea.

Em suma, "le recours à l'Histoire a [...] pour but de retrouver l'origine et l'évolution des situations historiques. L'Histoire demeure la caution de fait des évènements, le droit en apprécié la validité. Le recours à l'Histoire n'a pas uniquement de valeur pédagogique; dans une certaine mesure, Marsile est sensible à l'évolution des faits qui permet de rendre compte de leur signification [...]". ${ }^{44}$

Com vista a concluir este trabalho, vamos tratar, agora, da contribuição filosófico-política do De Translatione, conquanto o seu aspecto material não lhe confira tal atributo, como o escrevemos antes, pois se trata de "un ouvrage historique [...] veut en être la réfutation par l'Histoire [...] l'opuscule marsilien complète la démonstration entreprise dans le Defensor Pacis et la confirme, ${ }^{45}$ mas é possivel nele encontrar assertivas de tal natureza, as quais podem ser amplamente englobadas em cinco pontos principais, com vista, da parte de seu autor, a não só assegurar, de um lado, a legitimidade histórica do Império Romano Germânico, herdeiro do antigo Império Romano, mas também a sua autonomia política face às pretensões hierocráticas do papado, e ainda o direito de os principes eleitores elegerem o rei da Alemanha e imperador, sem que fosse necessário que a sua pessoa tivesse de ser confirmada pelo papa e depois, ter de ser coroada por ele.

Por isso, em primeiro lugar, a esfera de ação dos clérigos deve se restringir apenas às tarefas exclusivamente religiosas, conforme era o seu procedimento regular à época da Igreja Primitiva, quando apenas batizavam, ouviam confissões, sepultavam os mortos e pregavam o Evangelho. Este modo de atuar do clero foi alterado durante o pontificado de São Silvestre e o governo do imperador Constantino I, o qual concedeu àquele papa o governo da Itália e de outras regiões do Ocidente.

44 Cfr. Introdução, p. 341.

45 Ibidem, p. 341. 
Em segundo lugar, todo o grupo clerical, pouco importam as dignidades que eles possuam, não tem autoridade para escolher alguém como rei, muito menos como imperador, e tampouco para depô-los, ainda que sejam inúteis ou professem alguma heresia. Não tem, outrossim, competência para desobrigar ninguém de cumprir o juramento de fidelidade que prestaram a um potentado secular, mormente tratando-se de um rei ou do imperador, mesmo que porventura sejam notoriamente conhecidos como hereges. Igualmente năo tem o poder de isentar os súditos de pagar impostos às autoridades secuiares e proibir que estas os cobrem e os arrecadem, porque, de um lado, não receberam de Cristo um poder que se estende à esfera secular, e de outro, pelo fato de a autoridade política, numa dada sociedade, caber àquela pessoa que foi escolhida para governá-la. Portanto, só conforme os escritos elaborados pelos próprios clérigos os atos dos papas Zacarias, que depôs o rei franco Childerico e elevou Pepino à realeza daquele povo; de Estêvão II, que teria ordenado a translação do império dos gregos para os francos; de Gregório III, que condenou como herege o imperador Leão III e seus partidários por não venerarem as imagens de Cristo e dos santos e ainda tomou outras medidas politicas contra ele, carecem totalmente de um fundamento legal.

Terceiro: a escolha do governante de uma sociedade deve ser feita ou por meio da aclamação do povo, do qual o clero faz parte, juntamente com os demais grupos sociais, ou através da eleição efetuada pelo grupo ou pessoas mais importantes da mesma ${ }^{46}$ Foi consoante a primeira modalidade de escolha justamente 0 que ocorreu com Carlos Magno e como Otão I. Foi de acordo com o segundo procedimento que Pepino se tornou rei dos francos e os sucessores de Otão III foram eleitos imperadores, porque a monarquia eletiva é o melhor regime politico, visto que se procura sempre indicar a pessoa mais apta ao governo.

Em quarto lugar, as decisões de interesse da sociedade, antes que venham a ser transformadas em lei, inicialmente hão de ser debatidas e aprovadas pelo povo ou pelo grupo mais importante que o representa e, depois, aprovadas pelo governante. Algo de semelhante deve ocorrer no seio dos grupos sociais, inclusive entre os clérigos, ainda que se trate de questões puramente religiosas, ou problemas disciplinares em que estejam envolvidos, ou que ainda se refiram à nomeação dos mesmos para os cargos eclesiásticos. Foi por isso que Carlos Magno, em face do pedido de ajuda que o papa Adriano I lhe havia pedido contra Desidério, rei dos Lombardos, primeiramente reuniu uma assembléia de nobres e prelados para deliberar sobre o assunto. Como o parecer dos mesmos sobre a questão tivesse sido favorável, atendeu à súplica do papa e marchou para a Itália com suas tropas. Foi também por esta razão que o próprio Carlos, noutra ocasião, veio novamente a Roma para apurar se as acusações de crimes que imputavam a Leão III tinham ou não fundamento. Dado que, perante ele e o povo, reunido na Basílica de São Pedro, ninguém comprovou as acusações contra o papa, e este jurou inocência, sob os evangelhos, foi considerado isento de culpa por todos os presentes naquele local. Foi ainda por aquela razão que, passado um bom tempo, numa altura em

46 Como o próprio Marsilio o indica, o fundamento desta tese encontra-se na primeira parte de o Defensor da Paz, capítulos 13, 14, 15 e 18. 
que a Igreja era governada por um mau pastor, João XII, primeiramente, os cardeais, reunidos em um sinodo, deliberaram por pedir ajuda a Otăo, rei da Alemanha, o qual, depois, veio até Roma, reuniu um concilio de cardeais para tratar daquele problema, e tendo acolhido a sugestão dos mesmos, dado que o papa não se emendava, optou por sugerir-lhe que renunciasse, e como este permanecesse irredutível, acabou por depô-lo.

Por último, as translações do poder imperial, tendo em vista, como ocorreram, foram perfeitamente legais.

Todavia, Marsílio de Pádua ao se referir tanto à questão da translação quanto à criação do colégio de príncipes eleitores, como poderá ser visto mais adiante, utiliza expressões vagas e indeterminadas, tais como, foi estabelecido, foi efetuada, não dizendo explicitamente quem teria tomado aquelas providências, tendo deixado uma brecha para seus adversários o rebaterem. 